NASA Technical Memorandum 106230

\title{
Experimental Evaluation of a Cooled Radial-Inflow Turbine
}

Lizet Tirres

Sverdrup Technology, Inc.

Lewis Research Center Group

Brook Park, Ohio

and

L. Danielle DiCicco and Brent C. Nowlin

National Aeronautics and Space Administration

Lewis Research Center

Cleveland, Ohio

Prepared for the

29th AIAA Joint Propulsion Conference and Exhibit cosponsored by the AIAA, SAE, ASME, and ASEE Monterey, California, June 28-30, 1993

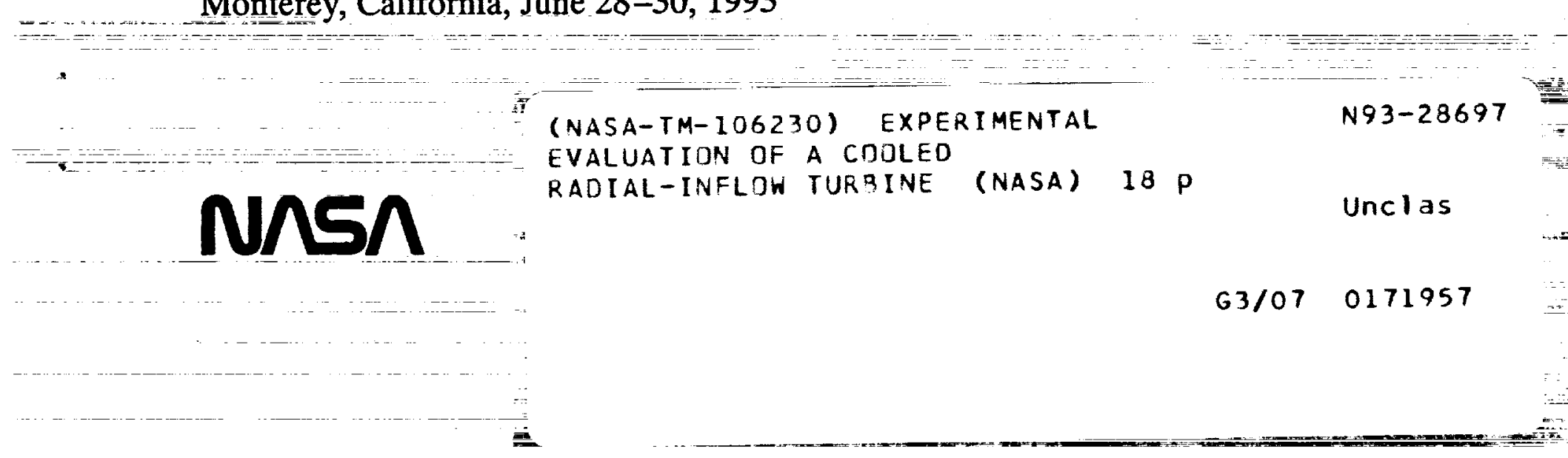




$-1 \quad-1$

$\div-$

$-$

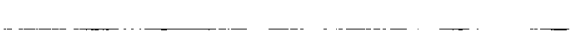




\title{
Experimental Evaluation of a Cooled Radial-Inflow Turbine
}

\author{
Lizet Tirres \\ Sverdrup Technology, Inc. \\ NASA Lewis Research Center Group \\ Brookpark, Ohio \\ and \\ L. Danielle DiCicco and Brent C. Nowlin \\ NASA Lewis Research Center \\ Cleveland, Ohio
}

\begin{abstract}
Two 14.4 inch tip diameter rotors were installed and tested in the Small Engines Component Turbine Facility (SECTF) at NASA Lewis Research Center. The rotors, a solid and a cooled version of a radial-inflow turbine, were tested with a 15 vane stator over a set of rotational speeds ranging from 80 to 120 percent design speed $(17,500$ to $21,500 \mathrm{rm})$. The total-to-total stage pressure ratios ranged from 2.5 to 5.5. The data obtained at the equivalent conditions using the solid version of the rotor are presented with the cooled rotor data. A Reynolds number of 381,000 was maintained for both rotors, whose stages had a design mass flow of $4.0 \mathrm{lbm} / \mathrm{sec}$, a design work level of $59.61 \mathrm{Btu} / \mathrm{lbm}$, and a design efficiency of $87 \%$. The results include mass flow data, turbine torque, turbine exit flow angles, stage efficiency, and rotor inlet and exit surveys.
\end{abstract}

\section{Introduction}

While the radial turbine has been used for a variety of small engine applications, it has been limited by its inlet temperature. This limit is imposed by the properties of the rotor material. Specific power output varies directly with turbine inlet temperature; as turbine inlet temperature increases cycle thermal efficiency improves. To achieve higher inlet temperatures, the development of rotor technology branches in two directions -- ceramic materials and turbine-blade cooling. Uncooled ceramic technology is not yet mature enough to make the presence of ceramic radial-inflow turbines commonplace, except in a limited number of automotive applications. While turbine blade cooling techniques have been applied extensively to axial turbine designs, this is not the case for radial turbines.

Radial turbines, however, offer several advantages over axial configuratations. For the same engine requirements, a radial turbine stage can supply the same amount of power as two axial stages. By replacing two axial stages, the total number of rotating parts

This work is declared work of the U.S. Government and is not subject to copy right protection in the United States. decreases, possibly reducing engine weight. In addition to decreasing the complexity of the stage, a radial configuration will have fewer blades to cool. However, fabrication of cooled radial turbines proves to be a serious challenge.

This challenge is illustrated by the attempts of various American engine companies in programs conducted in conjunction with NASA and the Army. The earliest program, described in Reference 1, used investment casting of $\mathbb{I N 1 0 0}$ to produce a cooled nozzle and rotor. Reference 2 explains a hot isostatic pressure (HIP) method used to bond a cast MAR-M247 to a PA101 powder metal hub. Another program, documented in Reference 3, incorporates a lamination process. Sheets of directionally solidified (DS) MAR-M247 were bonded together to form the rotor. Finally, a split blade fabrication method allowed the design of a more complicated cooling scheme (Reference 4).

Current efforts in radial turbine cooling design draw upon the experience gained from the programs mentioned above. An excellent overview is given by Roelke in Reference 5. NASA Lewis Research Center and Allison Gas Turbine Division have been involved in a joint effort to evaluate the aerodynamic performance and the heat transfer characteristics of a cooled radial-inflow turbine. NASA and the Army first designed an in-house version of the turbine, which Allison then modified, and later fabricated two rotors. While both of the rotors had the same extemal geometry, one was solid, and the other had internal blade cooling passages. In Reference 6, Snyder and Roelke describe the rotor and include the rotor cooling design requirements. Reference 7 is Allison's final report on the design and fabrication of the air-cooled, high-temperature radial turbine.

This report presents a portion of the data taken for both the solid and cooled versions of this rotor. The data used to describe the aerodynamic performance includes data maps of the mass flow, torque, exit flow angle, and efficiency. Static pressures through the stage are also presented. A stator exit survey provides a contour map of the stator pressure ratio. Finally, a 
rotor exit survey shows the variation of total temperature, exit flow angle, total pressure ratio, and total stage efficiency across the span.

\section{Symbols}

\begin{tabular}{|c|c|c|}
\hline$\Delta \mathrm{h}^{\prime}$ & - & specific work, Btu/lbm \\
\hline $\mathrm{N}$ & -- & turbine speed, rpm \\
\hline $\mathbf{P}$ & - & static pressure, psia \\
\hline $\mathbf{P}^{\prime}$ & -- & total pressure, psia \\
\hline $\mathrm{T}$ & - & temperature, ${ }^{\circ} \mathrm{F}$ \\
\hline$\eta^{\prime}$ & - & total efficiency \\
\hline$v$ & - & blade-jet speed ratio \\
\hline Subscripts: & & \\
\hline $0-4$ & -- & station number location \\
\hline A & -- & ambient flow condition \\
\hline c & - & coolant flow \\
\hline D & -- & design value \\
\hline id & $=-$ & ideal work \\
\hline id,c & -- & ideal work, coolant flow \\
\hline L & -- & torque based value \\
\hline $\mathrm{N} 2$ & -- & $\mathrm{N}_{2}$ chilled coolant flow \\
\hline $\mathrm{p}$ & -- & primary (mass flow) \\
\hline $\mathbf{S}$ & -- & static condition \\
\hline$s$ & -- & solid rotor \\
\hline $\mathbf{t}$ & -- & total (mass flow) \\
\hline
\end{tabular}

\section{Turbine Description and Test Matrix}

The research goal for this program was to study the performance of a single radial turbine stage, depicted in Figure 1. The stator consists of 15 equally spaced vanes, each with a chord length of 5 inches. The incoming flow is tumed approximately 73 degrees before it enters the rotor. The experimental rotors are scaled up for ease of instrumentation and to match the Reynolds number at rig conditions. The engine-sized rotor has a tip diameter of 8.02 inches while the experimental rotor has a tip diameter of 14.4 inches. Figure 2 shows the critical dimensions of the experimental rotor such as, the b-width, as well as the leading and trailing edge locations of both the stator and the rotor. Each of the 13 rotor blades is internally cooled. After flowing through a preswirler, the coolant air enters the rotor through a series of ports at the backface of the rotor. Coolant flow passes through a series of passages and pin fin arrays before it is eliminated through slots at the trailing edge of the rotor. Figure 3 shows the internal coolant passages, while Figure 4 is a photograph of the slotted trailing edge.

The test matrix included variations of the stage pressure ratio, rotational speed, and coolant-to-primary temperature ratio. The design point conditions are based on the engine-sized rotor. Table 1 shows the design point values for this turbine and compares the engine conditions with both the engine equivalent conditions and the test rig equivalent conditions. The rotors were run at rotational speeds ranging from 15,580 to $23,370 \mathrm{rpm}$ ( $80 \%$ to $120 \%$ design spoed). The total-to-total stage pressure ratio ranged from 2.5 to 6.0. The ratio of the coolant temperature to the primary air temperature is defined as the coolant temperature ratio, $T_{c} / T_{\sigma}$. We used three coolant temperature conditions in our test matrix: $T_{c} / T_{0}=$ 0.445 (design), $T_{c} / T_{0}=0.650$ (ambient coolant), plus a speed line with no coolant flow. For each range of pressure ratios, a specific coolant temperature was maintained, and the coolant-to-primary mass flow rate was held constant. Table 2 shows the range of experimental operating conditions. Clearances varied slightly for the two turbine builds (solid and cooled rotor), and for the three coolant conditions. Table 3 shows the inducer, exducer, and backface clearances for each case run.

\section{Apparatus, Instrumentation, Procedure}

The Small Engine Components Turbine Facility (SECTF) at the NASA Lewis Research Center was used to conduct the aerodynamic performance evaluation. This unique continuous-flow facility was designed to test turbines for use in small engine applications (Reference 8). With the current piping, turbines up to approximately 15 inches in diameter can be installed and tested in the rig, which accommodates either radial or axial-flow, cooled or uncooled turbines.

The main facility components are shown in Figure 5. The rig is provided with dry compressed air and altitude exhaust from the NASA Lewis Research Center Central Services Systems. The altitude exhaust system can supply the facility with vacuum pressures down to 2 psia. While the Central Services System does supply the facility with compressed air up to 140 psia, turbine inlet pressure is limited to 40 psia to accommodate the research hardware. A rupture disk is used as a safety device to prevent over-pressurization of the rig. The maximum flowrate through the facility is approximately $12 \mathrm{lbm} / \mathrm{s}$. Two electro-hydraulic control valves allow the operator to set the desired pressure ratio across the turbine. Once the turbine inlet pressure is set, the operator uses the exhaust control valve to change the back pressure, and correspondingly, the pressure ratio.

The primary air can be heated in two different ways. An electric heater is used only when the desired turbine inlet temperature is below $250^{\circ} \mathrm{F}$; for this testing, a natural gas combustor is used to raise the inlet temperature to $400{ }^{\circ} \mathrm{F}$. The maximum primary air temperature that the facility can sustain is $800^{\circ} \mathrm{F}$. The 
flowrate of the natural gas is measured by a turbine meter. The products of combustion are taken into consideration during analysis through a gas properties subroutine in the data reduction program.

The research turbine shaft is mechanically coupled to an in-line torquemeter which can be configured to measure up to 5,124 in-lbf. An eddy current dynamometer (maximum speed 25,000 $\mathrm{rm}$ ) provides speed control of the research turbine and can absorb up to 1,250 HP. A 2.735:1 gearbox allows turbine speeds up to $60,000 \mathrm{rpm}$ with a minimum controllable speed of $4,100 \mathrm{rpm}$. The torque limit is $6,624 \mathrm{in}-\mathrm{lbf}$ at 12,000 $\mathrm{pm}$. These conditions define the operating envelope of the facility and are represented graphically in Figure 6.

To accommodate the requirements of this program, a system to provide chilled cooling air to the research turbine was installed (see the schematic in Figure 4). Cooling air is supplied continuously by the 140 psia combustion air service to the facility. After passing through a liquid nitrogen heat exchanger, the chilled air is automatically mixed with ambient air to obtained the desired coolant temperature. The mixed air is measured by a venturi meter and then feeds a manifold behind the research turbine. Cooling air temperatures have ranged down to $-77^{\circ} \mathrm{F}$ upstream of the preswirler (prior to entering the turbine blades). Liquid nitrogen to the heat exchanger is provided through an external dewar. The duration of a test run for a cooled turbine is limited by the capacity of the liquid nitrogen dewar, but is still on the order of several hours. Testing time of uncooled turbines is virtually unlimited.

The instrumentation for the aerodynamic evaluation of the cooled radial-inflow turbine consisted primarily of static pressure taps, total pressure and temperature rakes (stations 0 and 4), actuated total pressure and temperature probes (stations 2 and 3), as weil as tip clearance probes (between stations 2 and 2.8). Figure 7 shows the location of the research instrumentation. Cooling air temperatures used in the research calculations were measured upstream of the preswirler plate mounted behind the rotor hub.

The instrumentation provided the parameters necessary for the performance evaluation. Total pressures from the inlet rakes and the stator exit survey probe were used to calculate the pressure ratio across the stator, while total pressures from the stator inlet and turbine exit pressure rakes provided the pressure ratio across the turbine. The efficiency calculation required measurements from the torquemeter, as well as from the inlet and exit pressure and temperature rakes. The measurements from the total temperature rakes at the exit were corrected for Mach number effects according to the techniques of Reference 9. The exit rakes function properly over an angle range of $\pm 15^{\circ}$. The actuated total pressure survey probes downstream of the turbine measured the span-wise variation of the exit flow angle. These surveys provided the angle settings for the exit pressure and temperature rakes. The tip clearance probes measured the dynamic inducer and exducer clearances during rotation of the rotor.

\section{Results and Discussion}

\section{Turbine Performance}

Mass Flow: Three flow rates were measured in this experiment: fuel, main air, and coolant air. The primary air flow is defined as the sum of the fuel flow and the main air flow. The total flow rate refers to the summed values of the coolant air, main air, and fuel flow rates. The equivalent mass flow is calculated from the primary flow rate. Figure 8 illustrates the variation of the equivalent mass flow as a function of equivalent stage pressure ratio: Figure 8(a) shows the mass flow data for the solid rotor, Figure 8(b) the cooled rotor data.

As seen in Figures 8( $a$ and $b$ ), the stage achieves choked conditions near the design pressure ratio (4.05). The figures indicate that the stage is choked in the stator because of the converging curves at the extreme pressure ratios. They also show that the mass flow for the cooled rotor is approximately 4 to 5 percent less than that for the solid rotor and that this difference occurs in the arc of the curves. At design pressure ratio, the experimental equivalent mass flow for the solid rotor was $99.4 \%$ of the design point equivalent mass flow; for the cooled rotor, it was $99.8 \%$.

Torque: Figure 9 presents the equivalent torque for lines of constant speed over a range of stage pressure ratios: the variation of solid rotor equivalent torque with pressure ratio is shown in Figure 9(a), while Figure 9(b) shows the cooled rotor equivalent torque variation. The design point equivalent torque is indicated for reference on both figures. At design conditions, the solid turbine equivalent torque is 531 in-lbf. The experimental equivalent torque is $2 \%$ less than the design equivalent torque at the design point, which is $541.8 \mathrm{in}-\mathrm{lbf}$. At the design point, the cooled rotor has an equivalent torque of $526.23 \mathrm{in}-\mathrm{lbf}$, which is $6.4 \%$ less than design value. Notice that as the rotational speed decreases and the pressure ratio increases, the turbine torque increases.

Turbine Exit Flow Angle: Figure 10 shows the exit flow angle over the tested pressure ratio range for each constant speed line for the solid rotor, Figure 10(a), and the cooled rotor, Figure $10(\mathrm{~b})$. The design value is also shown on the plots. Three radial-survey probes located 
at the midspan location on different circumferential locations measured the exit flow angle. The values presented here are an average of these three probes at midspan. Note that the exit flow angle for the cooled rotor is approximately 4 degrees less than the flow angle for the solid rotor. The figures show that flow angle increases in the positive direction with increasing speed and decreasing pressure ratio. By definition, the flow angle is positive in the direction of rotation.

Efficiency: The turbine total efficiency was based on the measured inlet and exit total pressures and measured turbine torque. Figure 11 shows the total efficiency as a function of blade-jet speed ratio for a range of rotational speeds. The design blade-jet speed ratio for this turbine is 0.71 . The solid circles in the figure represent the solid rotor data with speeds ranging from 80 to 120 percent design speed. The cooled rotor data (for $T_{c} / T_{0}=0.445$ ) is shown for speeds ranging from 90 to 110 percent design For blade-jet speed ratios less than design, the solid rotor data shows that the efficiency remains constant as the ratio decreases. The trend of this data varies from the trends shown in both examples of efficiency variation as a function of the blade-jet speed ratio given in Reference 10 . The examples show decreasing efficiencies as the blade-jet speed ratio decreases. The peak efficiency for the cooled rotor is 2 points lower than the peak efficiency of the solid rotor, due to the lower torque output that was measured. The efficiency calculation for the cooled rotor accounts for the work contributed by the coolant flow. The equation used to calculate the total efficiency for the solid rotor is as follows:

$$
\eta_{s}^{\prime}=\frac{\Delta h_{L}^{\prime}}{\Delta h_{i d}^{\prime}}
$$

where,

$$
\begin{aligned}
\Delta \mathbf{h}_{\mathrm{L}}^{\prime}= & \begin{array}{l}
\text { Turbine work based on torque, } \\
\text { speed, and total mass flow. }
\end{array} \\
\Delta \mathbf{h}_{\mathrm{id}}^{\prime}= & \begin{array}{l}
\text { Ideal work based on measured } \\
\text { stage pressure ratio and inlet } \\
\text { temperature. }
\end{array}
\end{aligned}
$$

Reference 11 describes the method used to calculate the total stage efficiency for the cooled rotor.

$$
\eta_{c}^{\prime}=\frac{\Delta h_{L}^{\prime} * w_{t}}{\Delta h_{i d}^{\prime} * w_{p}+\Delta h_{i d, c} * w_{c}}
$$

where,

$\Delta h_{L}^{\prime}=$ Turbine work based on torque, speed, and total mass flow, Btu/lbm.

$$
\begin{aligned}
& \Delta \mathbf{h}_{\mathrm{id}}=\text { Ideal work based on measured stage } \\
& \Delta \mathrm{h}_{\mathrm{idc}}^{\prime}=\text { Ideal work based on the coolant flow } \\
& \text { pressure ratio and the coolant flow } \\
& \text { inlet temperature, Btu/bm. } \\
& w_{t}=\text { Total mass flow (air, fuel, and coolant } \\
& \text { flows), lbm/sec. } \\
& \mathrm{w}_{\mathrm{p}}=\text { Primary mass flow (air and fuel } \\
& \text { flows), } \mathrm{lbm} / \mathrm{sec} \text {. } \\
& \mathrm{w}_{\mathrm{c}}=\text { Coolant mass flow, } \mathrm{lbm} / \mathrm{sec} \text {. }
\end{aligned}
$$

Figures 12(a-c), show the variation of total stage efficiency, $\eta$ ', with pressure ratio. The cooled rotor ran at three rotational speeds: $90 \%, 100 \%$, and $110 \%$ of design speed As described earlier and shown in Table 2 , the conditions of the coolant flow varied for the speed lines. The solid rotor efficiencies are as much as 2 points higher than those for the cooled rotor. The exception occurs at design speed with no coolant flow, Figure 12(b). Since there is no coolant mass flow $\left(w_{c}=\right.$ $0)$, the efficiency for $\eta_{c}^{\prime}$, equation 2 , reduces to equation $1, \eta^{\prime}$. . For the $100 \%$ speed line, the solid rotor data and the cooled rotor data with no coolant flow show the loss incurred by the rotor due strictly to the physical differences in the rotor and the two rotor builds. These differences amount to less than one half of an efficiency point. The contribution of work by the coolant flow (the ideal coolant work term -- $\Delta \mathbf{h}_{\text {id,cood }}$ * $w_{c}$ ) accounts for approximately 0.7 of a point loss in efficiency. A variation in the coolant temperature conditions did not cause a significant change in the efficiency of the cooled rotor and is in agreement with Reference 11. The difference between the onboard temperature of the ambient coolant and the $\mathrm{N}_{2}$ chilled coolant was 177 degrees $\left(T_{A}=100^{\circ} \mathrm{F}\right.$ and $T_{N 2}=.77$ $\left.{ }^{\circ} \mathrm{F}\right)$.

Finally, the plots in Figure 12 show that the efficiency becomes constant as pressure ratio increases. Because the pressure ratio varies inversely with the blade-jet speed ratio, the plots in Figure 12 are consistent with Figure 11. As shown in Table 1, this turbine has a design point efficiency of 0.87 . At design point, the cooled rotor produced an efficiency of 0.842 (3.2\% less than the design value), and the solid rotor produced an efficiency of $0.855(1.7 \%$ less than the design value). The solid rotor achieved a peak efficiency of 0.875 at $110 \%$ design speed at design pressure ratio, while the cooled rotor achieved its peak efficiency of 0.857 at the same experimental conditions.

Table 3 illustrates another aspect of the rotor losses. As mentioned earlier, the tip clearance probes 
monitored clearances during rotation. The table shows that the tip clearances vary slightly for each case. The dynamic clearance measurements increase slightly as the coolant flow temperature decreases. The backface clearance, a static measurement, varies between the two builds. Although the resulting changes in the clearances may be small, they still contribute to the overall loss and could account for a large part of the 2 point difference between the solid and cooled rotor.

\section{Internal Flow Characteristics}

Turbine Reaction: Figures 13(a and b) show static-to-inlet total pressure ratios, $P_{S} / P^{\prime}$, at design speed for selected total-to-total stage pressure ratios. The static-to-inlet total pressure ratios use the stator inlet (station 1), stator exit, vaneless space (station 2), rotor exit (station 2.8), near rotor exit (station 3), and far rotor exit (station 4) static pressures. Figure 13(a) shows the static pressure variation for the solid rotor, Figure 13(b) the static pressure variation for the cooled rotor. For corresponding stage pressure ratios, the solid rotor static pressures and cooled rotor static pressures are equivalent.

The figures show that the turbine builds have a positive reaction because the static pressure decreases through the stator, from station 1 to station 1.5 , and through the rotor, station 2 to station 2.5. They illustrate the $50 \%$ reaction design of the radial turbine; half the pressure drop occurs in the stator and half occurs in the rotor. The static pressure remains the same through the vaneless space, station 1.5 to station 2 , and through the stations at the rotor exit, stations 2.8 to 4 .

Rotor Inlet Survey: The total pressure probes at station 2 measured the total pressure through angular sweeps from hub to shroud at design conditions. Figure 14(a) shows two-dimensional total pressure ratio contours behind the stator. The plot shows the total-to-total stator pressure ratio through a stator pitch and across the span from hub to shroud. Figure 14(b) provides a view of the surface contour of the exit survey. It shows the effect of the stator, which is upstream from the probe. The lower pressure ratios indicate a higher loss and range from 0.99 to about 0.88 . The contour to the left of the wake corresponds to the pressure surface of the stator. The stator should produce a periodic wake (the contours at the extreme left should match the contours at the extreme right). A suction effect due to the spinning rotor and large, unequal clearance gaps may be the reason for the stator's lack of periodicity. Note that in the spanwise direction, the wake losses are greater near the hub than at the shroud ( $100 \%$ span). This nonuniformity could be due to the larger backface clearance at the rotor inlet (downstream from the probe) than the shroud clearance.

Rotor Exit Survey: Figures 15(a-d) show the results of the rotor exit surveys as a function of the fraction of the span for both rotors at three test conditions. The three cases shown in the figures include the design point $\left(\mathrm{P}^{\prime}\right.$ 。 $/ \mathrm{P}_{4}^{\prime}=4$ and $\mathrm{N}_{\mathrm{D}}=19475$ ), and two off-design points $\left(\mathrm{P}_{0}^{\prime}\right.$ $/ \mathrm{P}_{4}^{\prime}=3.5$ with $\mathrm{N}=0.90 \mathrm{~N}_{\mathrm{D}}$, and $\mathrm{P}_{0}{ }_{0} / \mathrm{P}_{4}=3.5$ with $\mathrm{N}=$ $1.10 \mathrm{~N}_{\mathrm{D}}$ ). The plots show surveys taken with the solid rotor and the cooled rotor (at $\left.T_{c} / T_{0}=0.445\right)$ for each case.

The total temperature ratios, shown in Figure 15(a), illustrate increasing total exit temperature from hub to tip $(0 \%-100 \%$ span). The survey readings at the 0.99 fraction span location show a large drop from the 0.91 fraction span location. The sudden decrease in temperature indicates that the probe is either inside of or too close to the casing. Therefore, the values for flow angle, efficiency, and total pressure at the 0.99 fraction span location should not be considered valid.

Figure 15(b) shows the variation of the exit flow angle across the span for the three cases. The flow angle surveys for the solid and cooled rotor at $90 \%$ and $100 \%$ design speeds show the same flow angle at locations less than $50 \%$ span. At locations greater than $50 \%$ span, the flow angle begins to vary by 2 to 3 degrees. Near the rotor shroud, $94 \%$ span, the difference between the solid and cooled rotor flow angles is 5 degrees for the $90 \%$ speed case and 3.5 degrees for the $100 \%$ speed case. For all survey cases the flow angle varies approximately 20 degrees from hub to shroud.

The total pressure ratio surveys for both rotors vary across the span, Figure 15(c). In the $90 \%$ and $100 \%$ design speed cases, the measured total pressure ratios are lower than average near the hub (between $10 \%$ and $40 \%$ span). The lower pressures indicate reduced flow in this region; however, the effect is not as pronounced at the $110 \%$ speed case.

The efficiencies calculated from the flow exit surveys, Figure 15 (d), vary by approximately 2.5 points between the solid and cooled rotor cases. These variations are of the same magnitude as the efficiencies shown in Figure 12. However, as plotted in Figure 15(d), the cooled rotor efficiencies are higher than those for the solid rotor. These efficiencies, unlike those shown in Figure 12, are based on the temperature drop through the stage. For the cooled rotor, the survey probes measured temperatures lowered by the discharged coolant air. The temperature drop through 
the stage is greater for the cooled rotor than the solid rotor, and for this reason, the surveyed efficiencies for the cooled rotor are higher than those for the uncooled rotor. The efficiency peaks between $10 \%$ and $20 \%$ span for all cases tested.

\section{Summary of Results}

The experimental performance of two versions of a cooled radial-inflow turbine has been determined in combusted air at nominal inlet total conditions of $\mathbf{3 0}$ psia and $400{ }^{\circ} \mathrm{F}$. These inlet conditions produce the prerequisites for operation at design Reynolds number for the corrected design mass flow and speed The rotational speeds ranged from $80 \%$ to $120 \%$ of design and the turbine-inlet-total to rotor-exit-total pressure ratio, $\mathrm{P}^{\prime} 0 / \mathrm{P}^{\prime} 4$, varied from 2.5 to 5.5 . A solid rotor was used for baseline aerodynamic data, and a cooled version was run at three coolant conditions. Mass flow, torque, and efficiency map the overall performance. Results of the rotor inlet and exit surveys are also presented.

The mass flow for both rotors was no more than $0.6 \%$ off the design condition, which was $4.00 \mathrm{lbm} / \mathrm{sec}$. The peak efficiencies of 0.878 (solid rotor) and 0.857 (cooled rotor) occurred at a pressure ratio of 4.05 (design) and at $110 \%$ design speed. At design conditions, the solid rotor showed an efficiency of 0.8551 ( $1.7 \%$ less than design), and the cooled rotor produced an efficiency of 0.8421 (3.2\% less than design). Observation of decreasing tip clearances illustrated clearance effects due to the coolant flow. Static pressures, monitored throughout the stage, showed the rotor to have a $50 \%$ reaction, as it was designed. The stator exit survey showed the stator wake. The rotor exit surveys recorded a 2 to 3 degroe difference in exit flow angle between the solid and cooled rotors. The surveyed efficiencies for the cooled rotor averaged 2.5 points higher than those for the solid rotor because the discharged coolant flow lowered the exit temperature.

The experimental work on the solid and cooled versions of this radial turbine provides a generous data base for the radial configuration. The information contained herein furnishes much-needed detailed information useful in the validation of current computational codes.

\section{References}

1. Calvert, G.S., Beck, S.C., and Okapuu, U., "Design and Experimental Evaluation of a High-Temperature Radial Turbine," USAAMRDL TR-71-20, 1971.
2. Tipton, D.L., and Monson, D.S., "High Temperature Radial Turbine Aero-Test," USAAVRADCOM TR-81-D-19, 1981.

3. Large, G.D., and Meyer, L.J., "Cooled, Variable-Area Radial Turbine Program," NASA CR-165408, 1982.

4. Hammer, A.N., Aigret, G.G., Psichogios, T.P., and Rodgers, C., "Fabrication of Cooled Radial Turbine Rotor," NASA CR-179503, 1986.

5. Roelke, R.J., "Radial Turbine Cooling," NASA TM-105658, 1992.

6. Snyder, P.H., and Roelke, R.J., "The Design of an Air-Cooled Metallic High Temperature Radial Turbine," AIAA Paper No. 88-2872, 1988.

7. Snyder, P.H., "Cooled High-Temperature Radial Turbine Program - II. Final Report," NASA CR 189122, 1992.

8. Nowlin, B.C., and Verhoff, V.G., "Small Engine Components Test Facility Turbine Testing Cell," ALAA Paper No. 88-2963, 1988.

9. Glawe, G., Holanda, R., and Krause, L., "Recovery and Radiation Correction and Time Constraints of Several Sizes of Shielded and Unshielded Thermocouple Probes for Measuring Gas Temperature," NASA TP-1099, 1978.

10. Glassman, A. J. ed. "Turbine Design and Application - Volume Three," NASA SP-290 (pgs. 56 and 133), 1975.

11. Goldman, L. J., "Cooled-Turbine Aerodynamic Performance Prediction from Reduced Primary to Coolant Total-Temperature-Ratio Results," NASA TN D-8312, 1976. 


\begin{tabular}{|c|c|c|c|}
\hline & \multicolumn{2}{|c|}{$D_{t}=8.021$ inches } & \multirow{2}{*}{$\begin{array}{c}D_{1}=14.4 \text { inches } \\
\text { Test-size } \\
\text { Equivalent }\end{array}$} \\
\hline & Engine-size & Equivalent & \\
\hline Rotor Inlet Total Temperature, $\left({ }^{\circ} \mathrm{F}\right)$ & 2300 & 59 & 400 \\
\hline Inlet Total Pressure, (psia) & 200 & 14.7 & 29.78 \\
\hline Mass Flow, $(\mathrm{lbm} / \mathrm{sec})$ & 4.56 & 0.79 & 4.00 \\
\hline Work, (Btu/lbm) & 186.85 & 36.12 & 59.61 \\
\hline Rotational Speed, (rpm) & 61900 & 27215 & 19475 \\
\hline Stage Pressure Ratio, $\left(\mathrm{P}_{0}{ }_{0} / \mathbf{P}_{4}^{\prime}\right)$ & 3.66 & 4.14 & 4.05 \\
\hline Uncooled Efficiency, $\left(\eta^{\prime}\right)$ & 0.87 & 0.87 & 0.87 \\
\hline Reynolds Number & 381622 & 197348 & 381622 \\
\hline Power, (hp) & 1205 & 40.45 & 337.21 \\
\hline Rotor Exit Total Temperature, $\left({ }^{\circ} \mathrm{F}\right)$ & 1674 & -91.49 & 158.78 \\
\hline Rotor Exit Total Pressure, (psia) & 54.57 & 3.55 & 7.35 \\
\hline $\mathrm{U}_{\mathrm{t}},(\mathrm{ft} / \mathrm{sec})$ & 2166.4 & 952.5 & 1223.7 \\
\hline Blade-jet Speed Ratio, ( $v$ ) & 0.66 & $-\cdots$ & 0.71 \\
\hline Rotor Coolant Supply Temp., $\left({ }^{\circ} \mathrm{F}\right)$ & 769 & $-\cdots$ & -30 \\
\hline On Board Coolant Temperature, $\left({ }^{\circ} \mathrm{F}\right)$ & 685 & $\ldots$ & -77 \\
\hline Coolant Temperature Ratio, $\left(\mathrm{Tc} / \mathrm{T}_{0}^{\prime}\right)$ & 0.415 & $\cdots$ & 0.445 \\
\hline Coolant Mass Flow, $(\mathrm{lbm} / \mathrm{sec})$ & 0.196 & --- & 0.1744 \\
\hline
\end{tabular}

Table 1. Design values of the rotor for engine conditions, equivalent conditions, and test conditions.

\begin{tabular}{|l|c|c|}
\hline Rotor \& Conditions & \% Speed Range & Pressure-Ratio Range \\
\hline Solid & $80-120$ & $2.0-6.0$ \\
\hline Cooled, No Coolant & 100 & $2.5-4.0$ \\
\hline Cooled, Ambient Coolant & $90-110$ & $2.5-5.5$ \\
\hline Cooled, $\mathrm{N}_{2}$ Cooled & $90-110$ & $2.5-5.0$ \\
\hline
\end{tabular}

Table 2. Range of experimental operating conditions for each coolant flow condition. 


\begin{tabular}{|l|c|c|c|}
\hline \multicolumn{1}{|c|}{ Cases } & Inducer & Exducer & Backface \\
\hline Solid Rotor & 36 & 16 & 58 \\
\hline No Coolant & 31 & 15 & 55 \\
\hline $\mathrm{T}_{\mathrm{c}} / \mathrm{T}_{0}^{\prime}=0.65$ & 37 & 16 & 55 \\
\hline $\mathrm{T}_{\mathrm{c}} / \mathrm{T}_{0}^{\prime}=0.445$ & 40 & 18 & 55 \\
\hline
\end{tabular}

Table 3. Averaged tip and backface clearances, in mils.

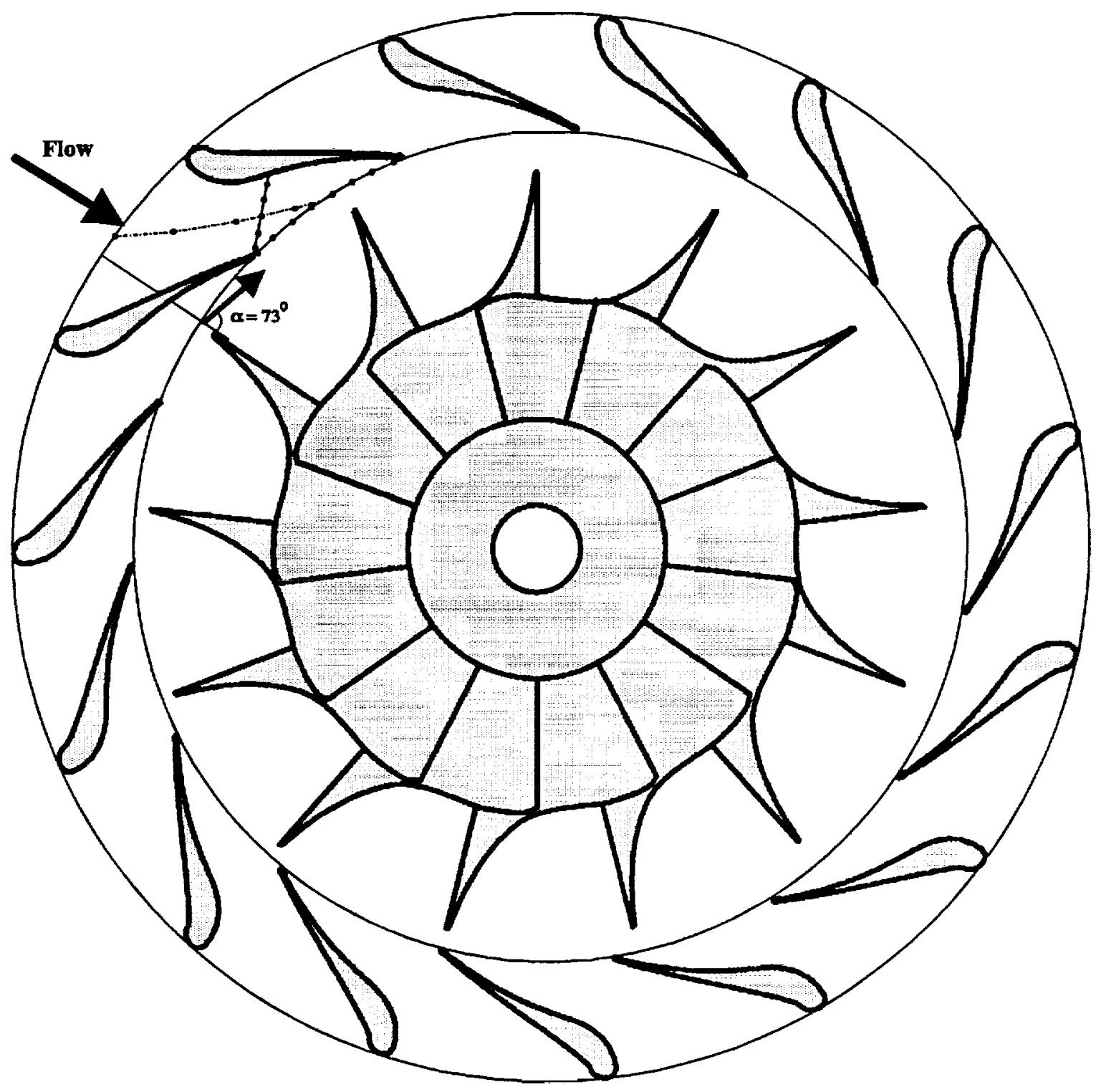

Figure 1. The radial turbine stage. 


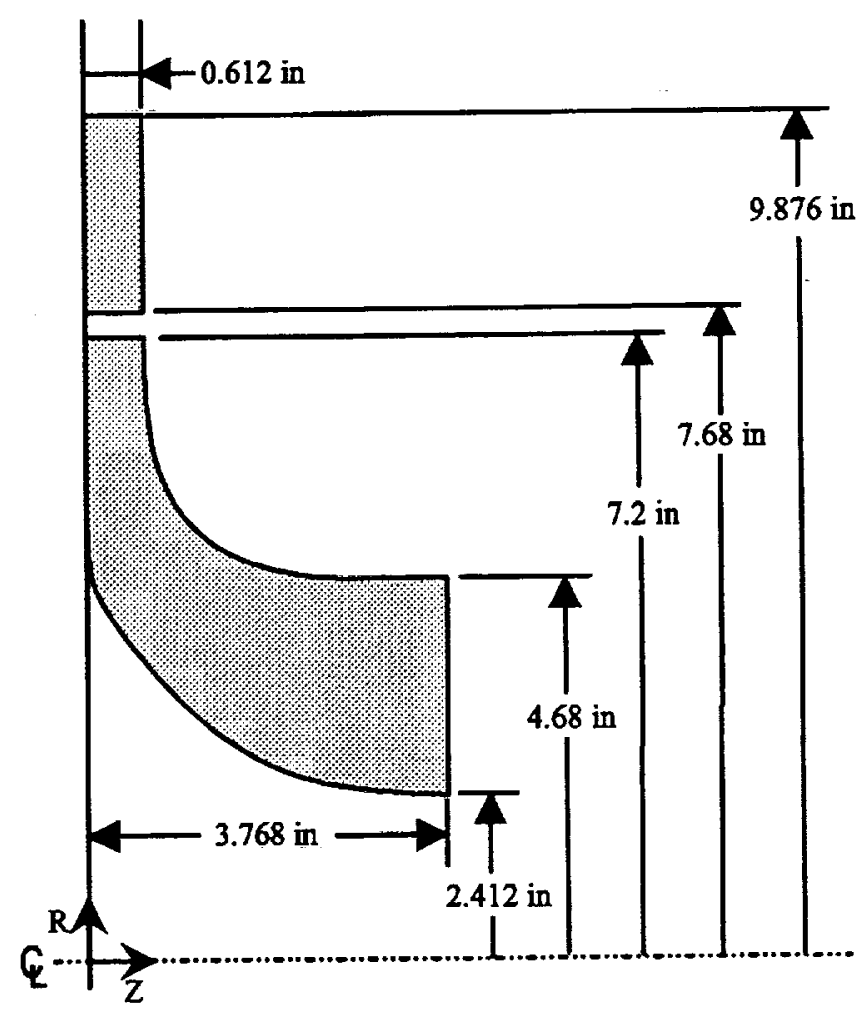

Figure 2. Stator and rotor dimensions.

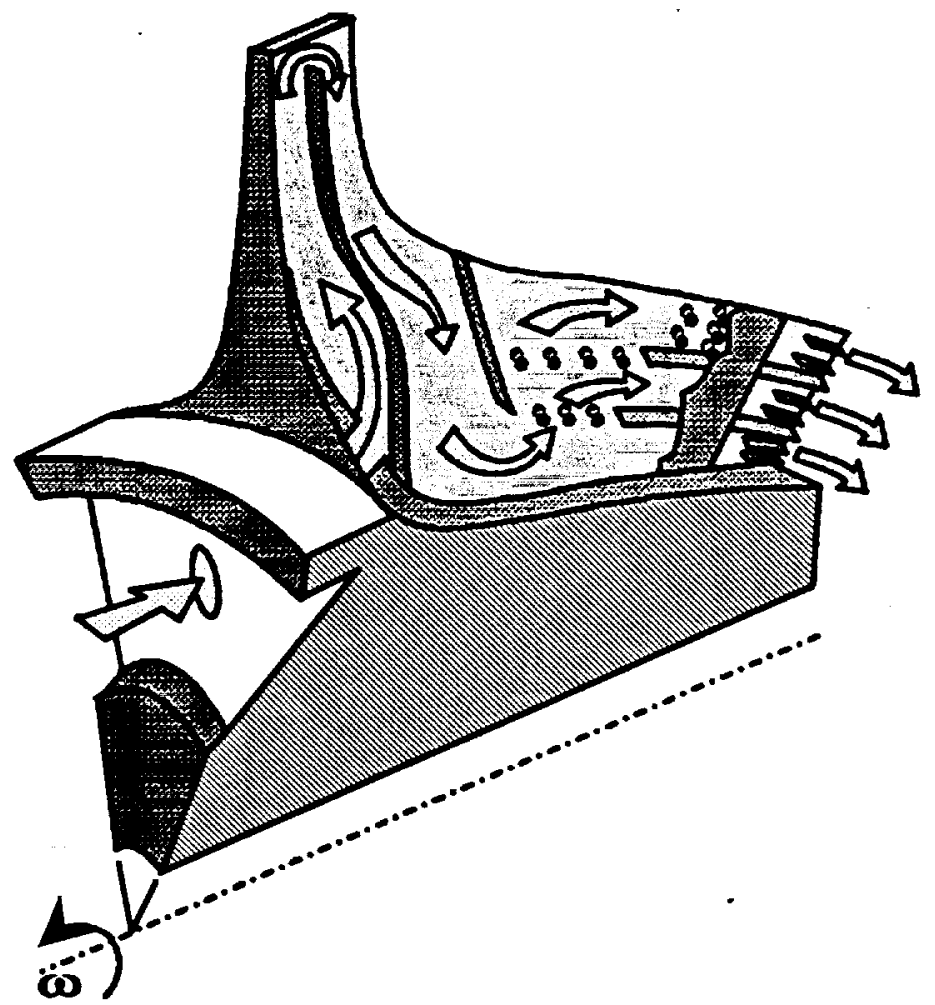

Figure 3. Internal coolant flow passages. 


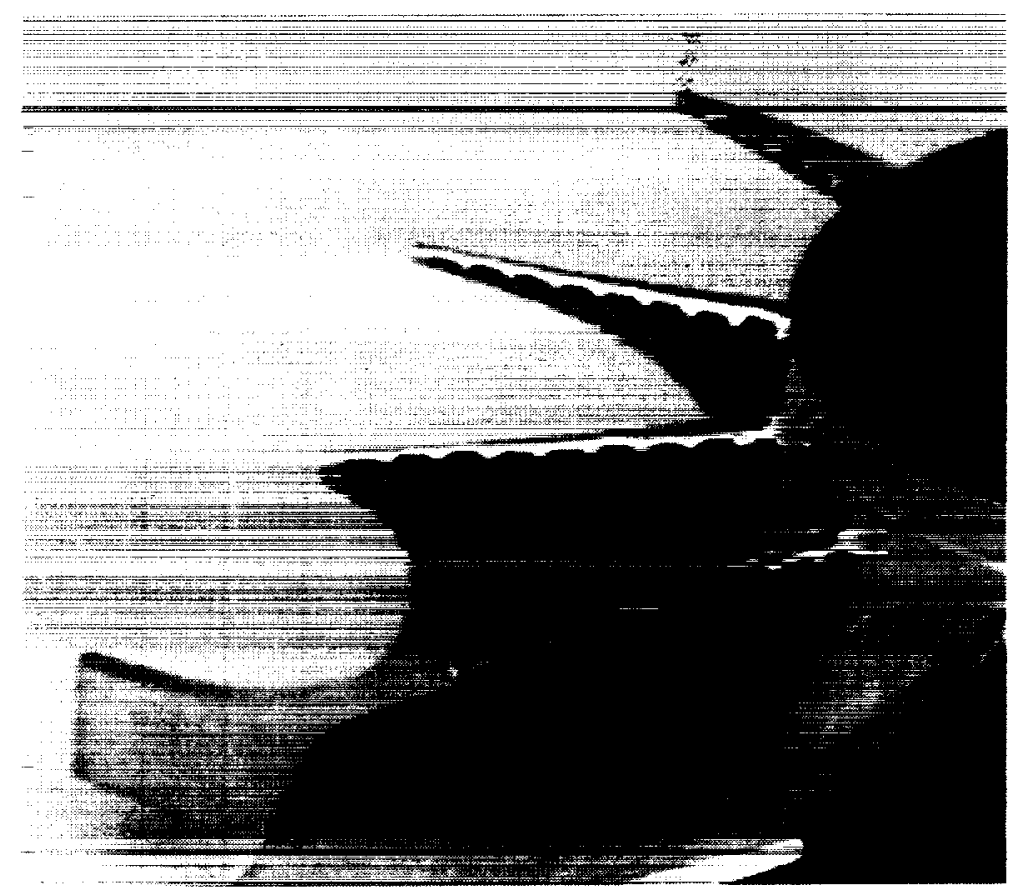

Figure 4. Slotted rotor training edge .

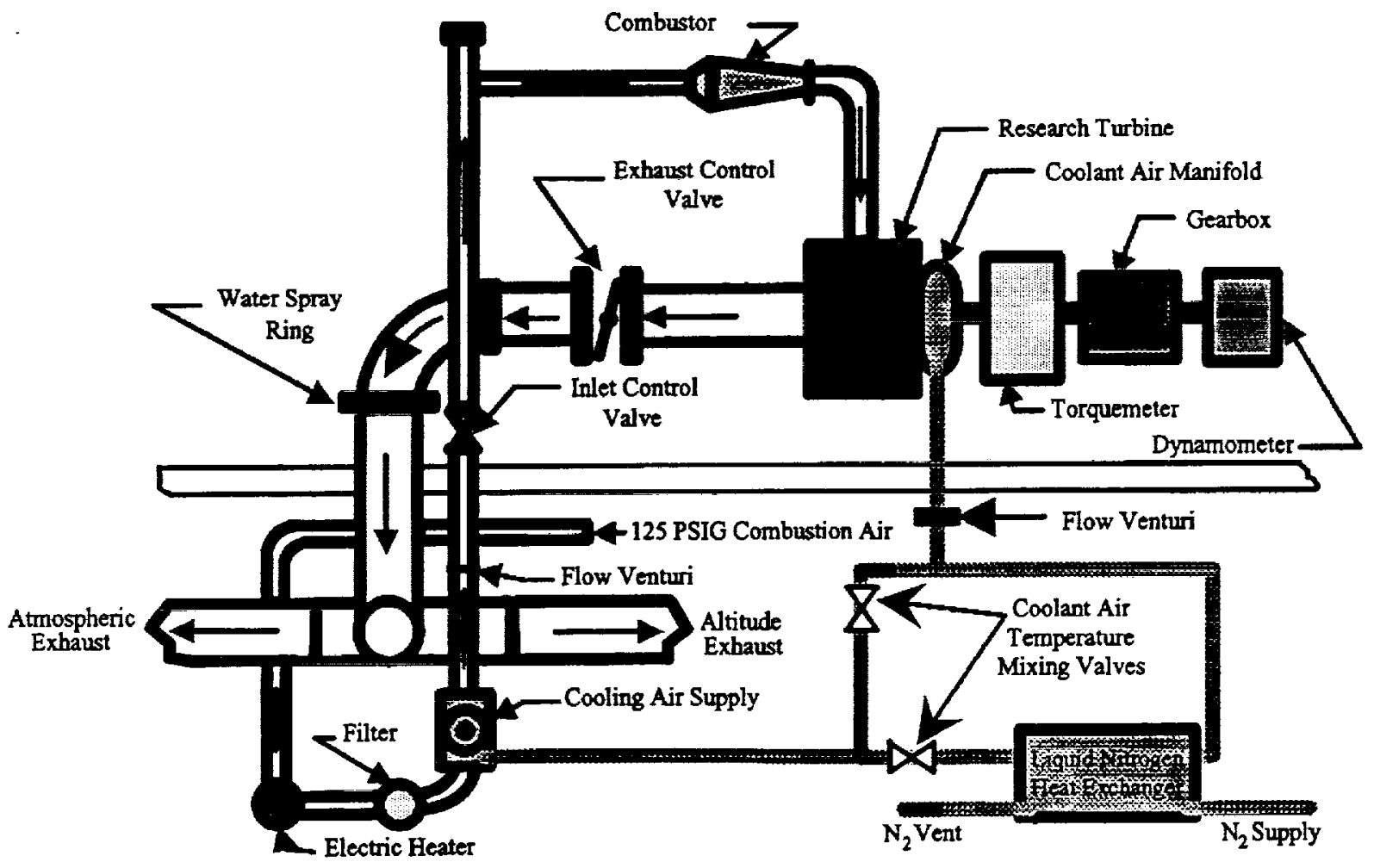

Figure 5. The Small Engine Component Test Facility (SECTF). 


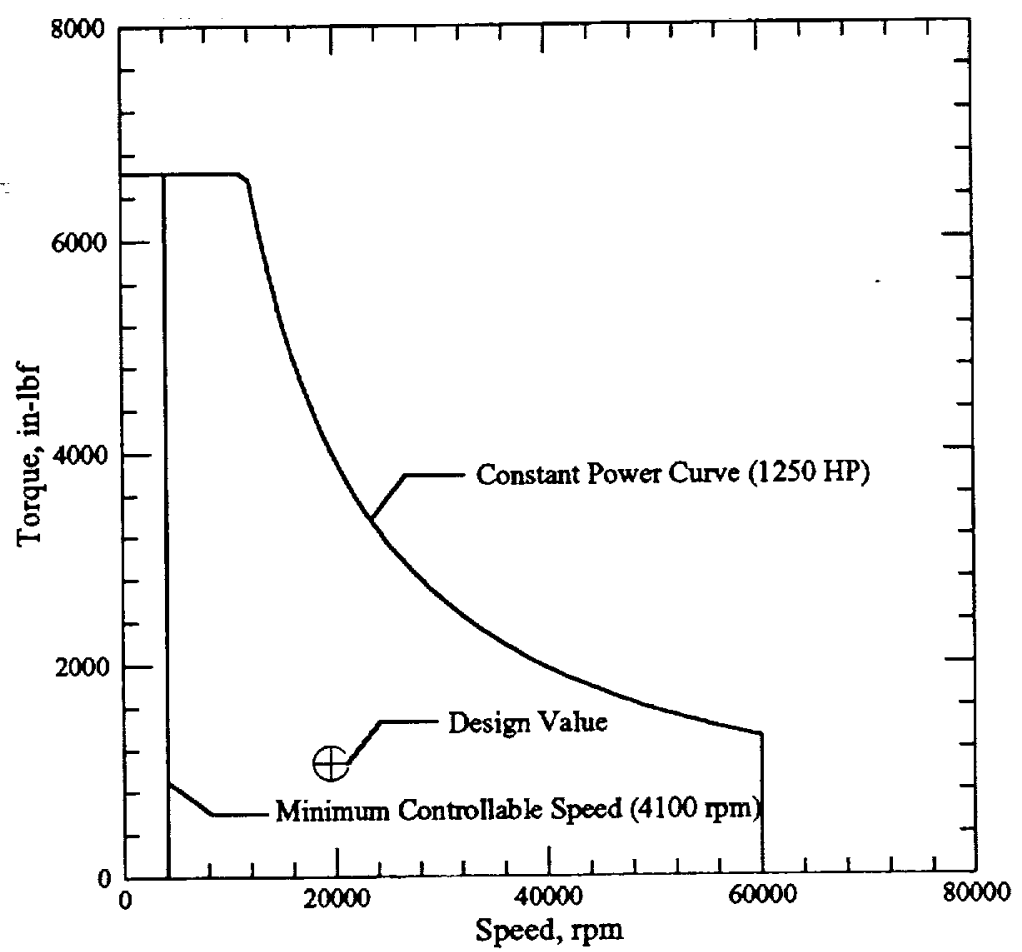

Figure 6. The SECTF operating envelope.

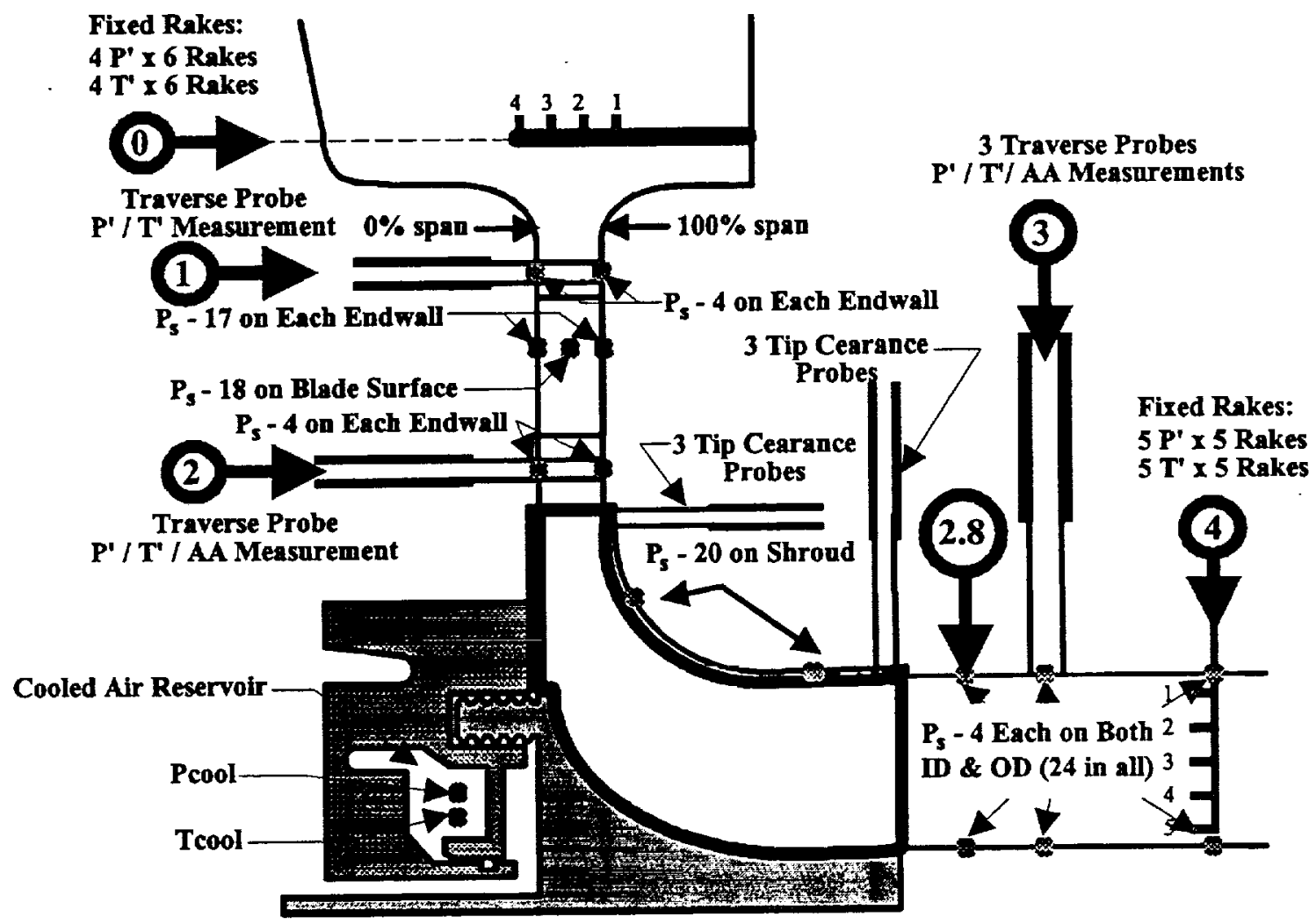

Figure 7. Research apparatus and instrumentation locations. 


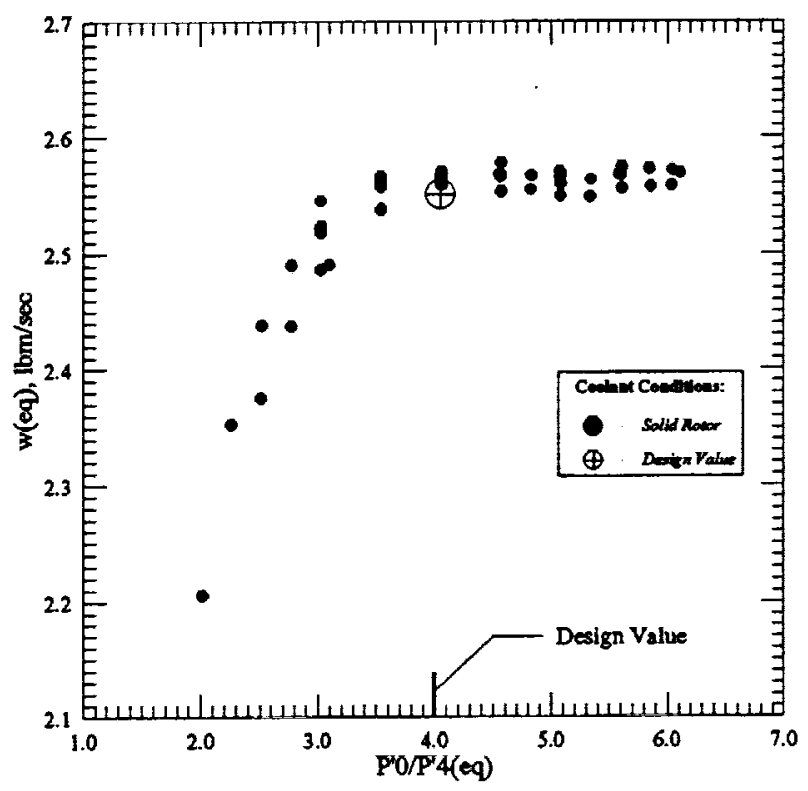

(a) The solid rotor.

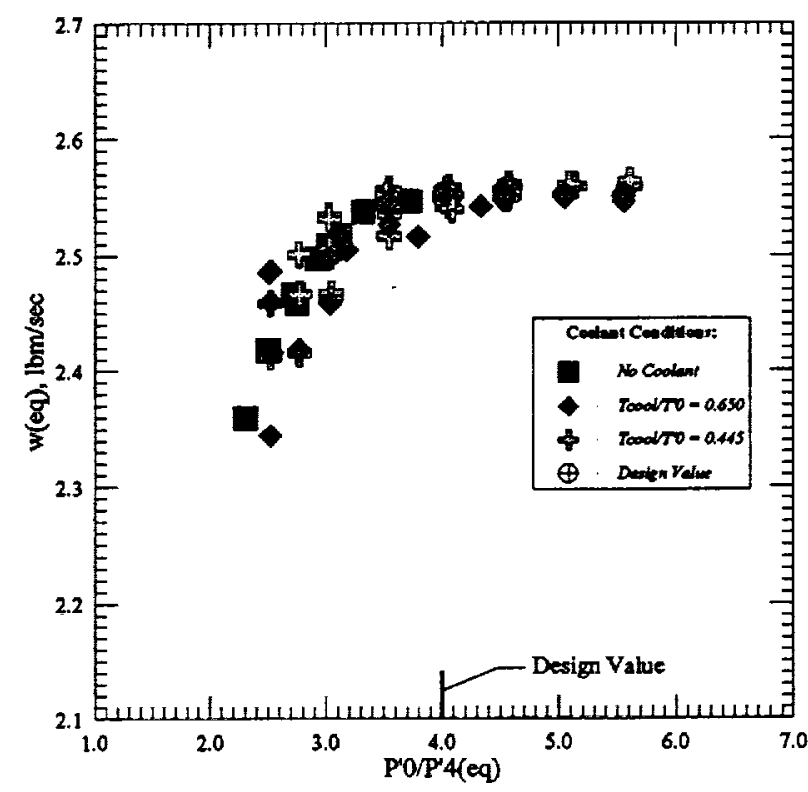

(b) The cooled rotor.

Figure 8. Variation of equivalent mass flow with total-to-total pressure ratio at three rotational speeds.

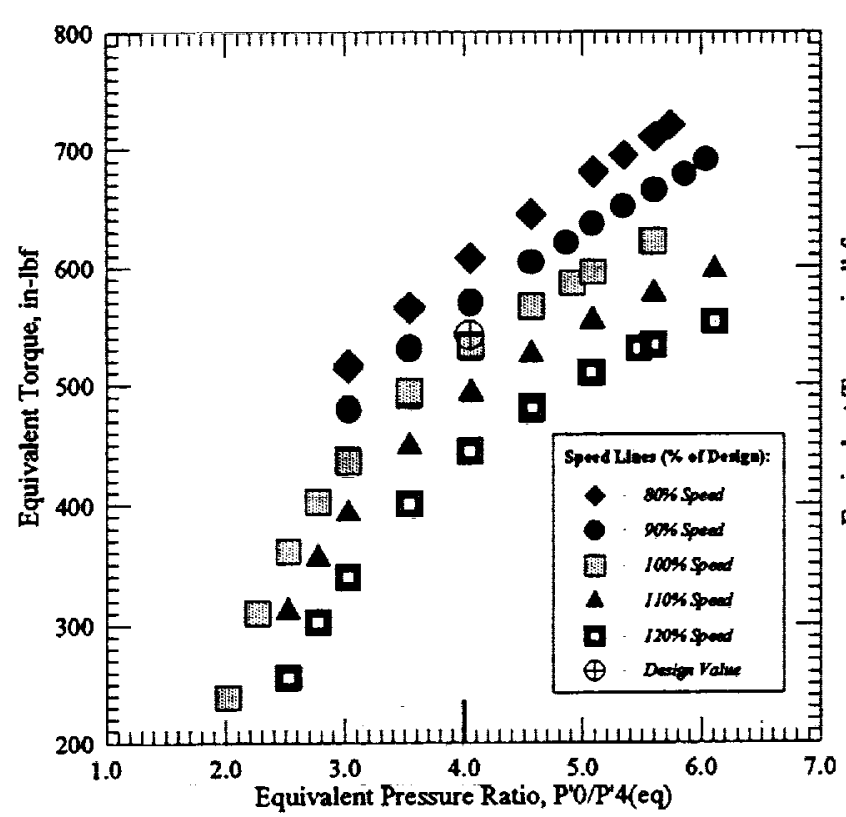

(a) The solid rotor.

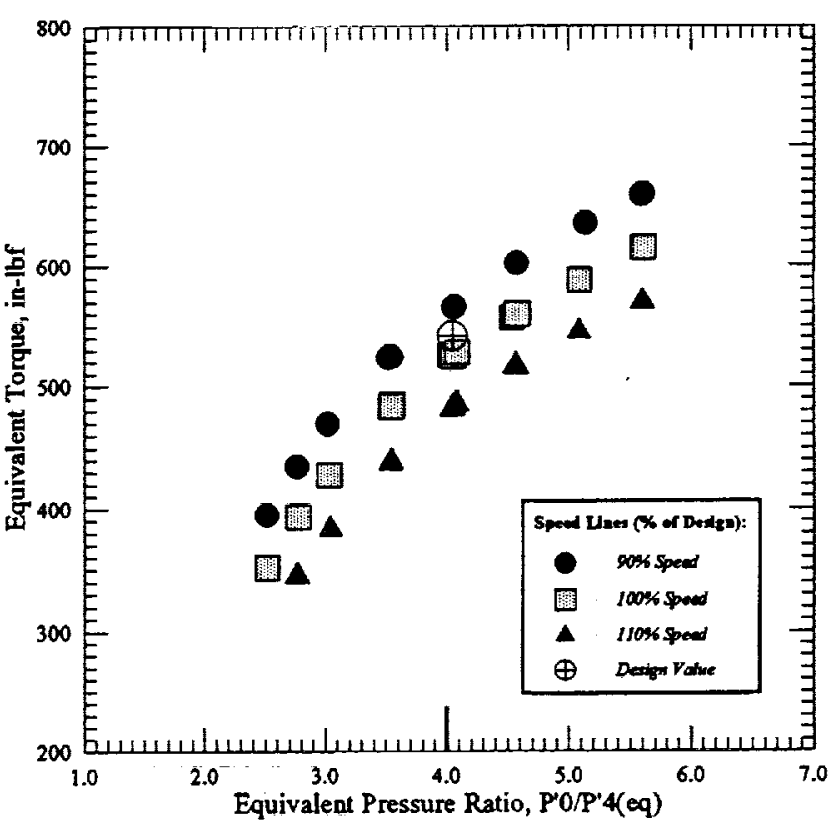

(b) The cooled rotor.

Figure 9. Variation of torque with pressure ratio for lines of constant rotational speed. 


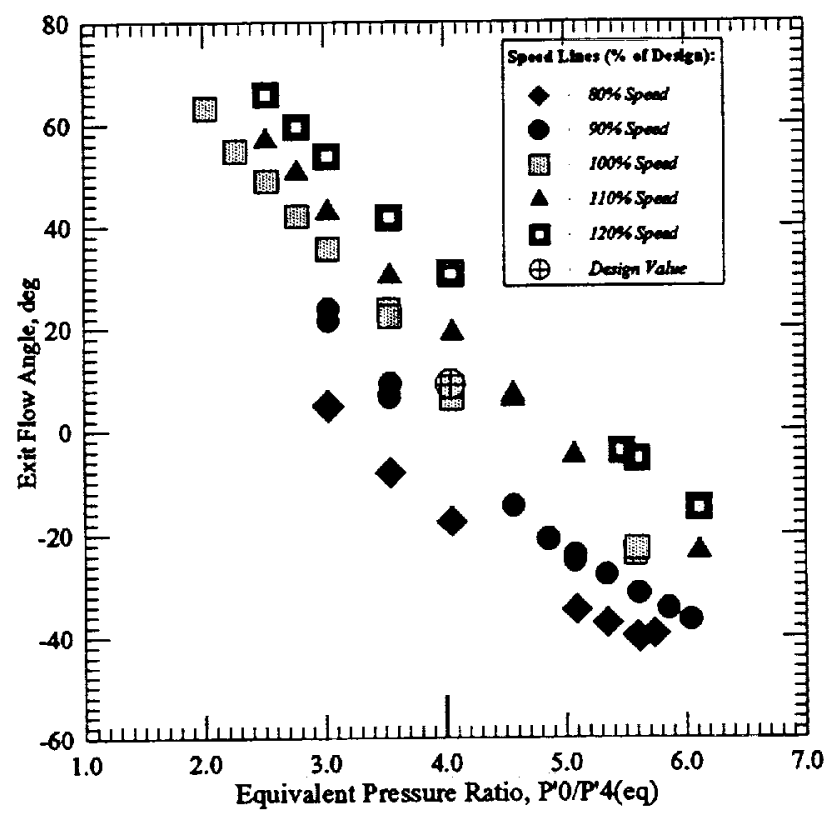

(a) The solid rotor.

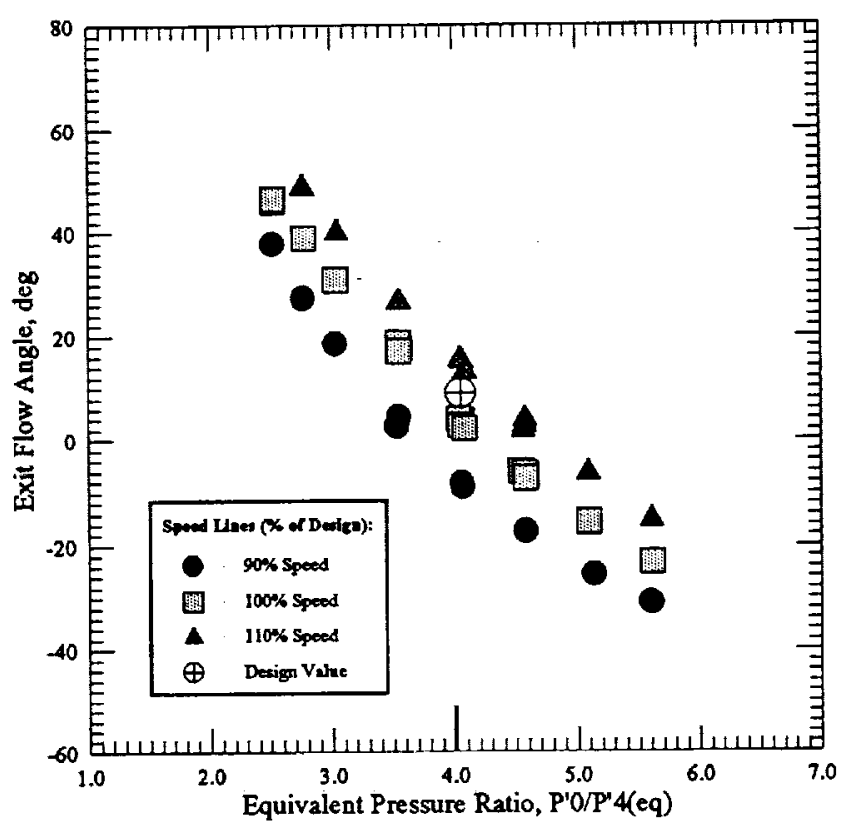

(b) The cooled rotor.

Figure 10. Variation of exit flow angle at mid-span with pressure ratio for lines of constant rotational speed.

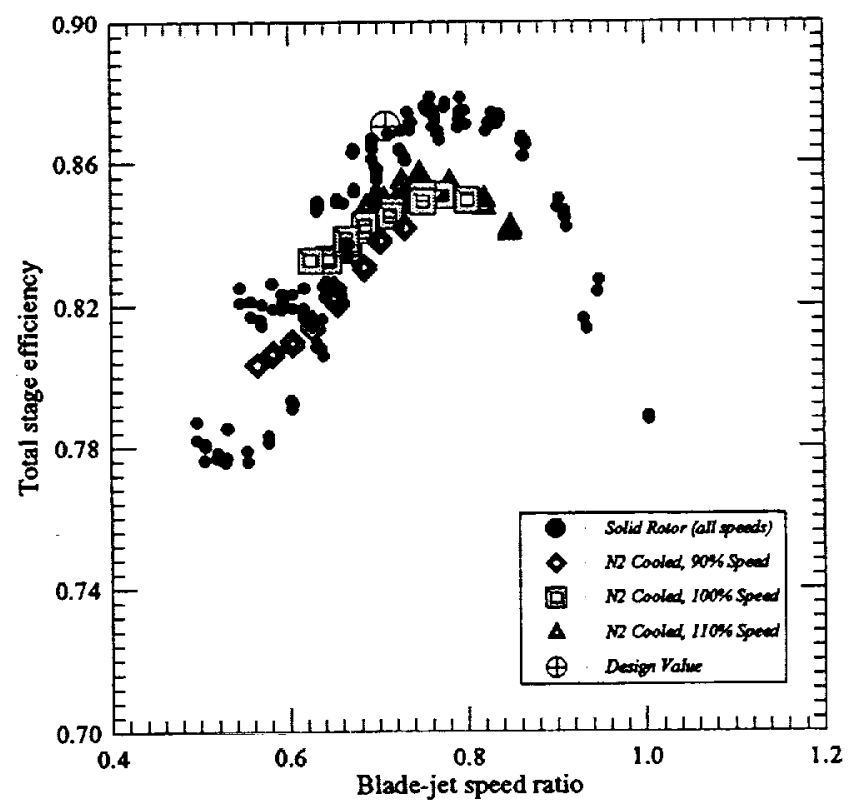

Figure 11. Variation of total stage efficiency, $\eta^{\prime}$, with blade-jet speed ratio, $v$. 


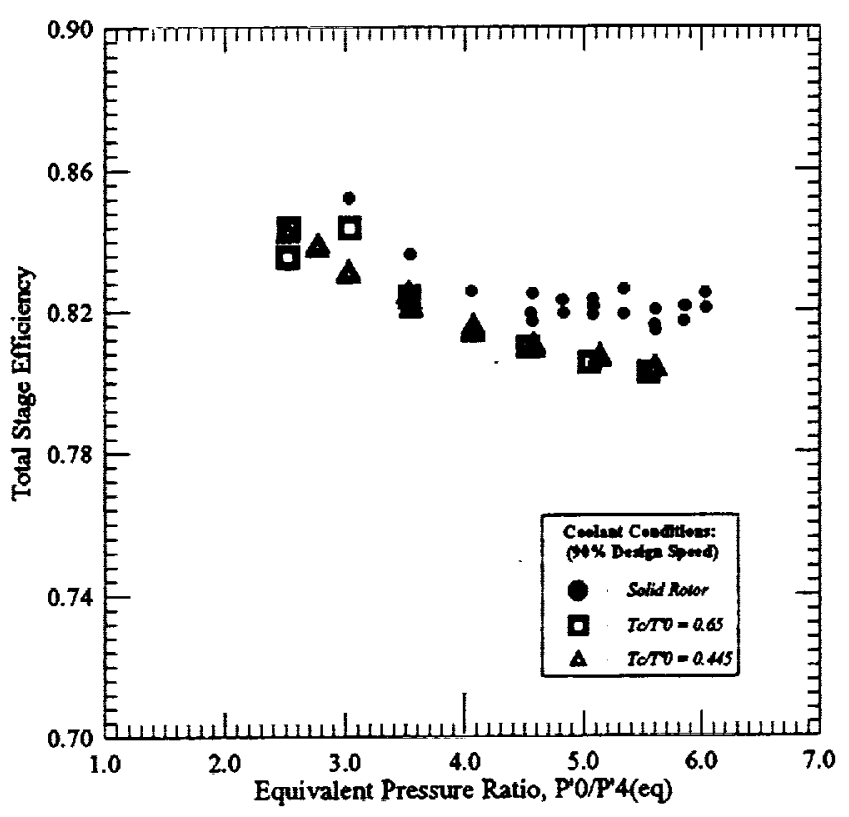

(a) Efficiency at $90 \%$ design speed.

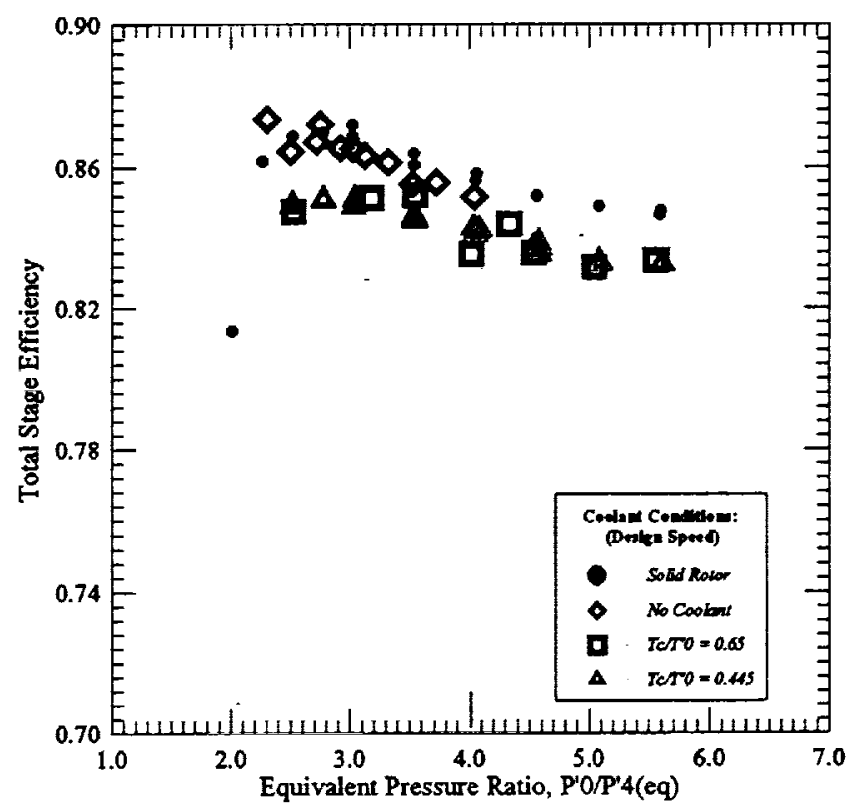

(b) Efficiency at design speed.

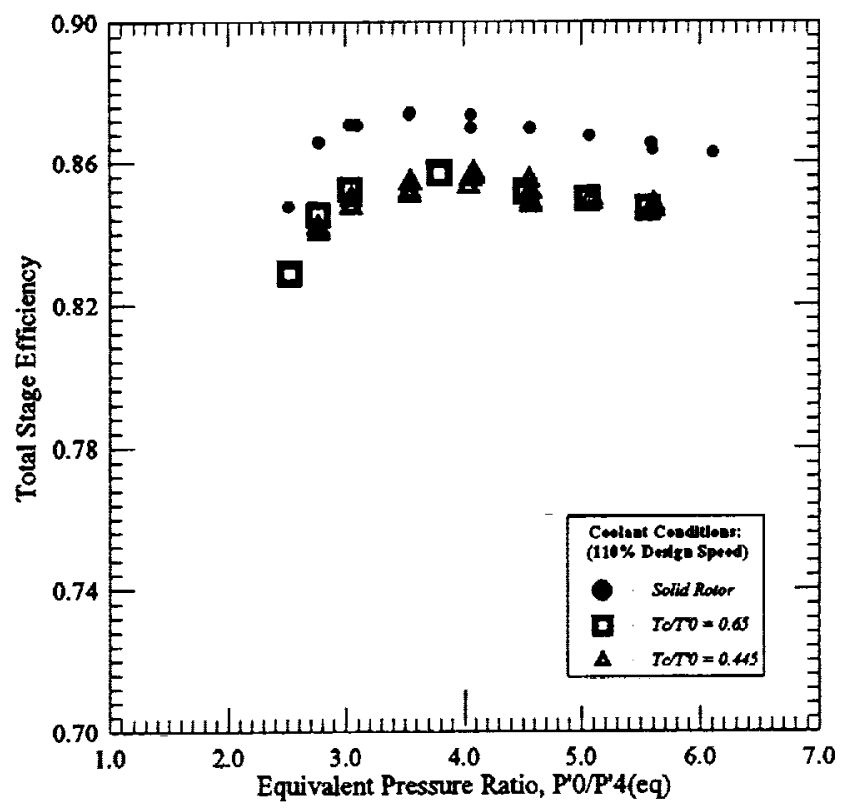

(c) Efficiency at $110 \%$ design speed

Figure 12. Comparison of the variation of the total efficiency, $\eta^{\prime}$, with pressure ratio for three rotational speeds at four test conditions. 


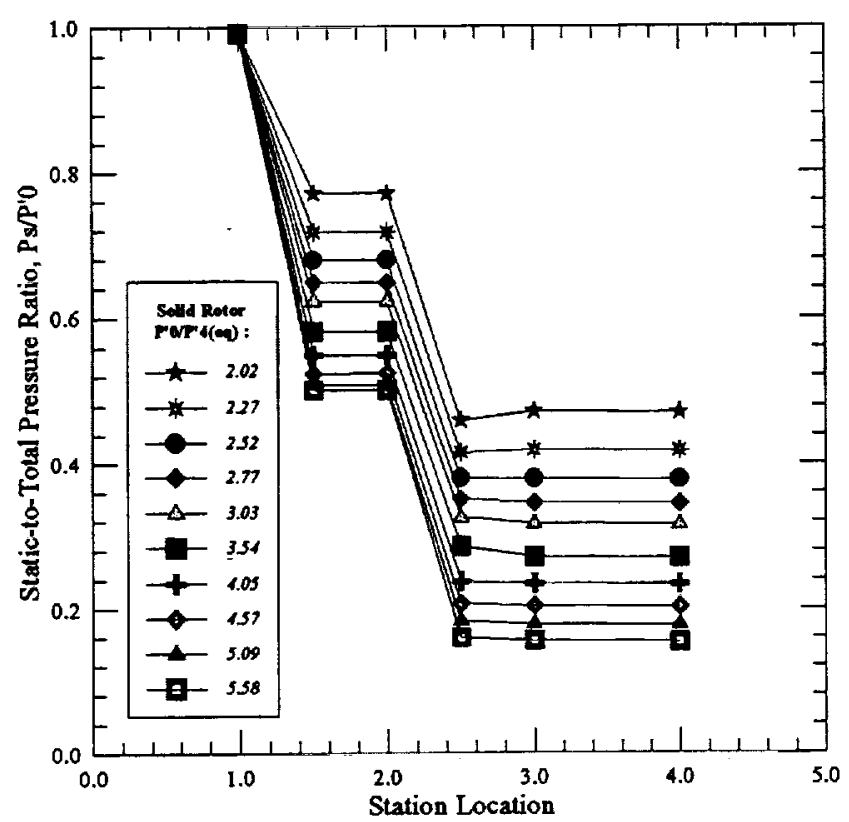

(a) The solid rotor.

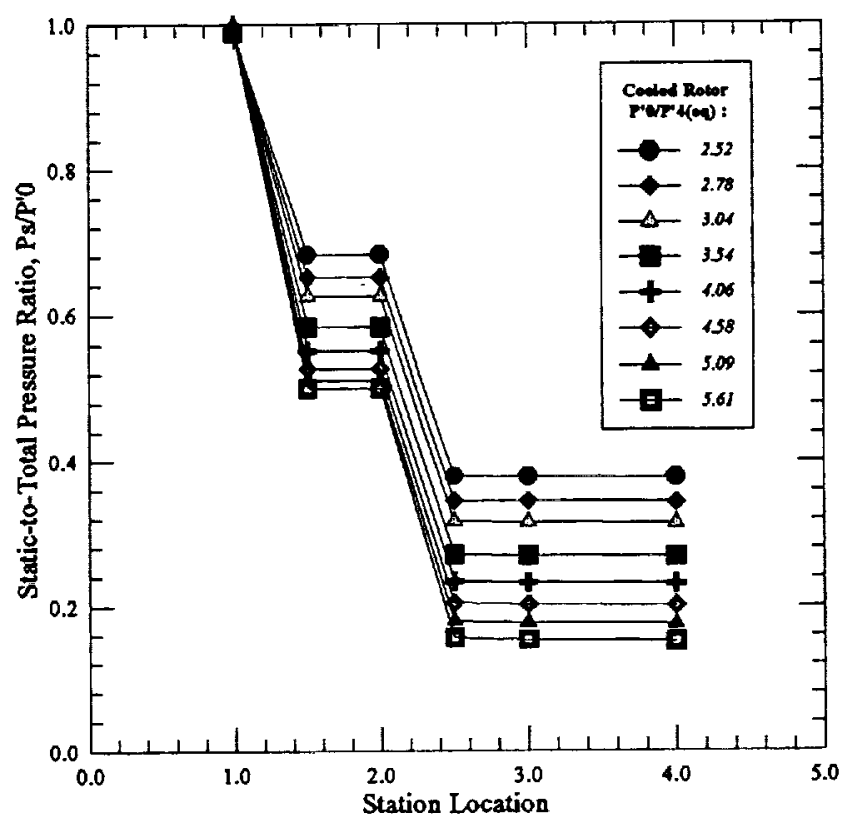

(b) The cooled rotor.

Figure 13. Variation of the static pressure through the turbine stage at design speed for both rotors.

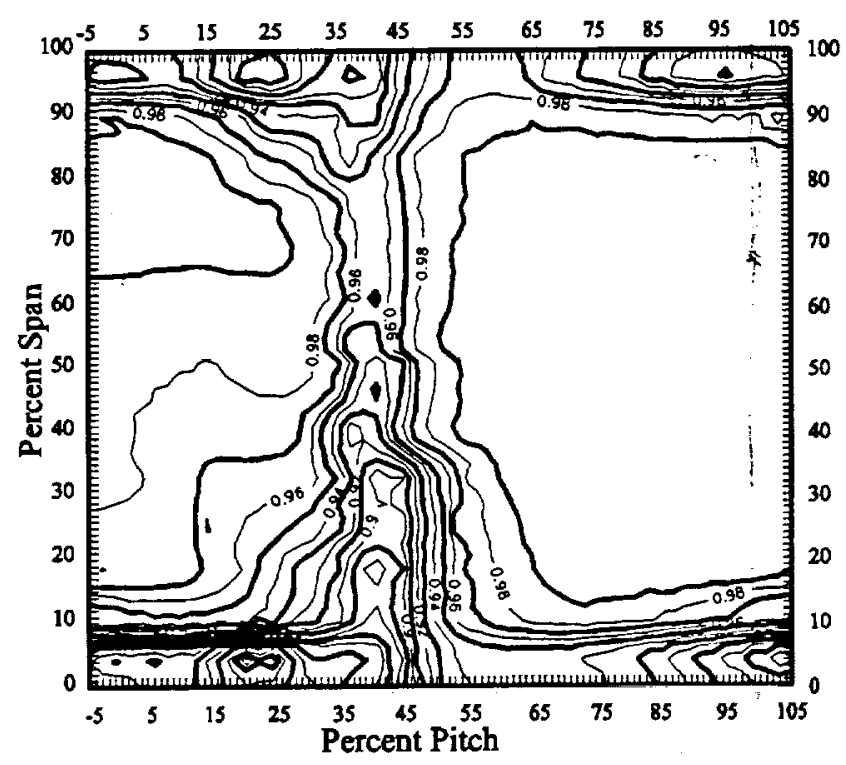

(a) Two-dimensional contour plot.

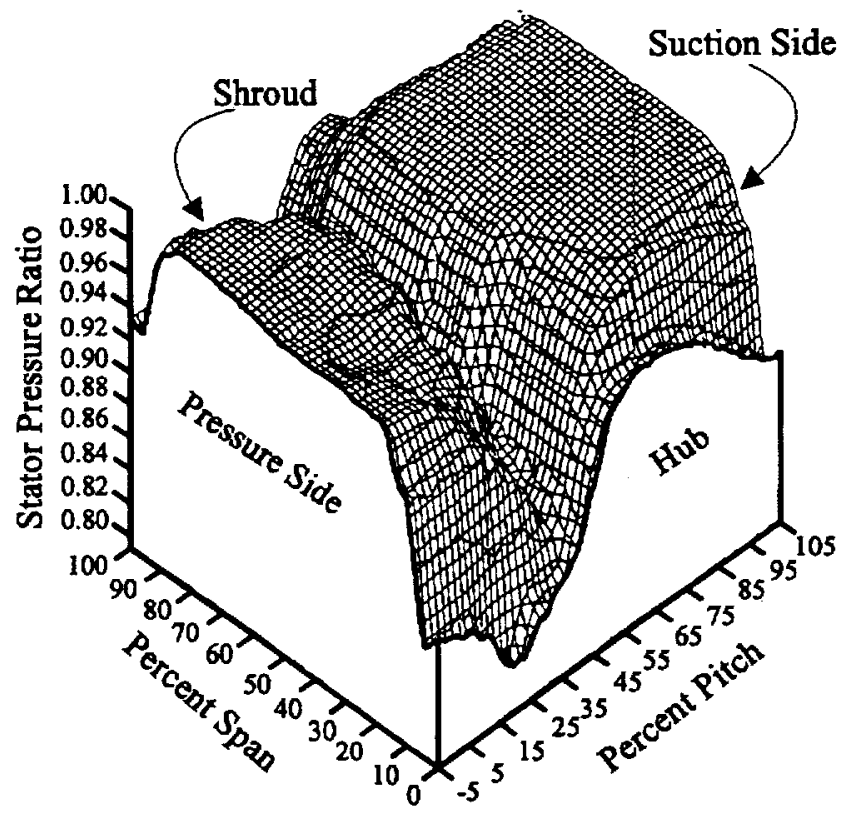

(b) Surface contour plot.

Figure 14. Contour plots of the stator pressure ratio, $\mathrm{P}_{2}^{\prime} / \mathrm{P}_{0}^{\prime}$, mapped in terms of percent of the trailing edge span and percent of the stator pitch. 


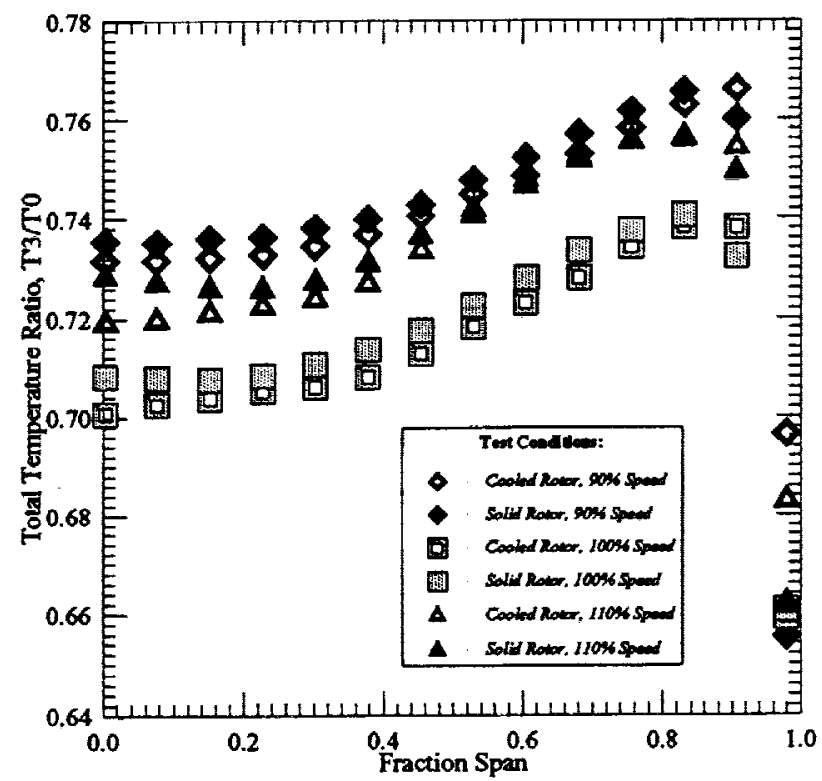

(a) Variation of total temperature, $T_{3} / T_{0}$, across the span.

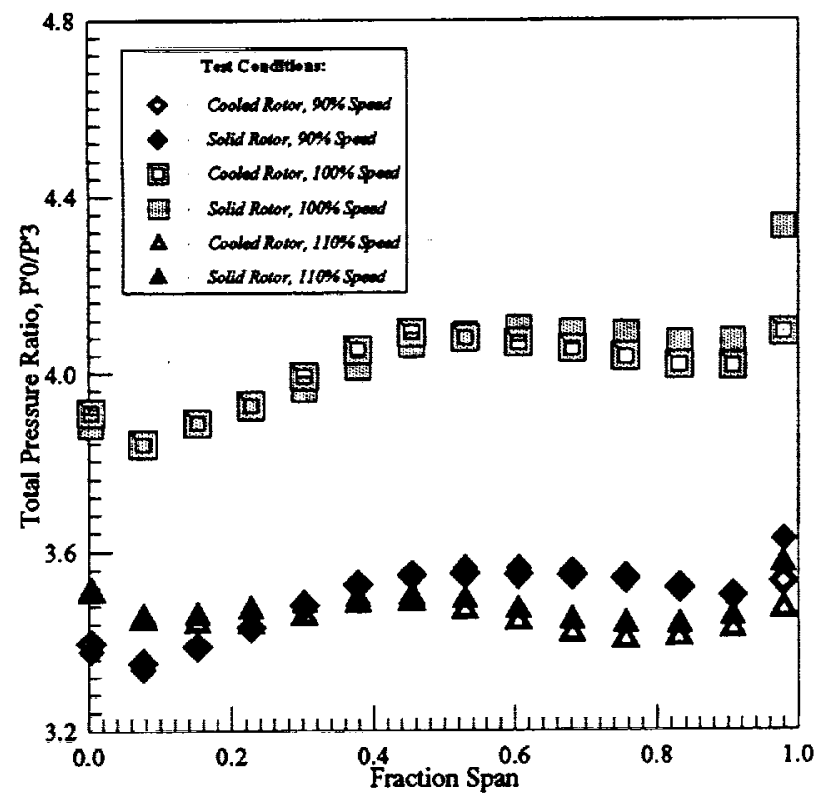

(c) Variation of total pressure ratio, $\mathrm{P}_{0} / \mathrm{P}_{3}^{\prime}$, across the span.

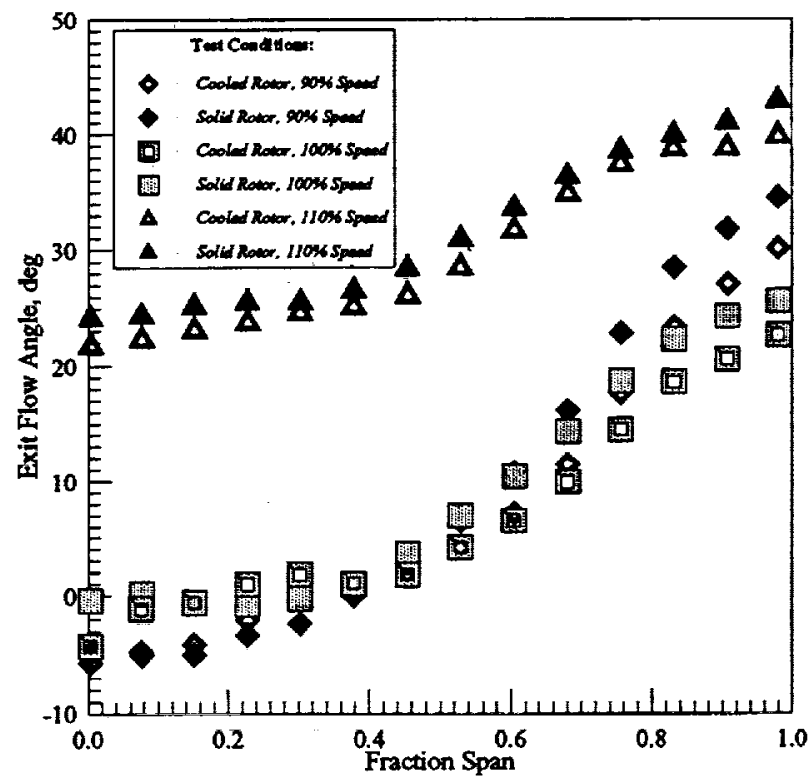

(b) Variation of exit flow angle, $\alpha$, in degrees across the span.

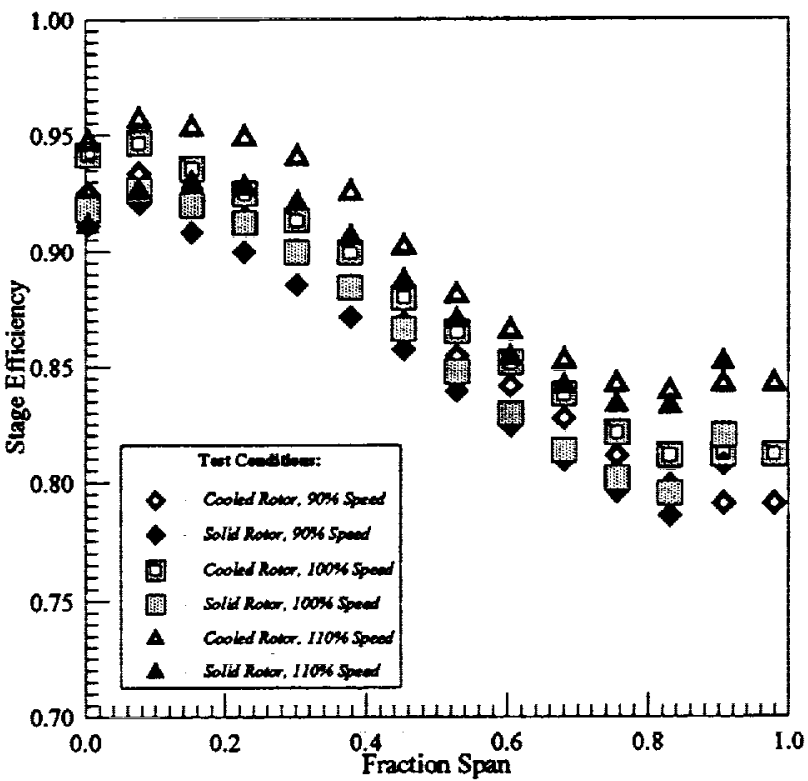

(d) Variation of the total stage efficiency, $\eta^{\prime}$, across the span.

Figure 15. Comparison between solid and cooled rotor exit surveys for three test conditions -- at $90 \%$ and $110 \%$ design speed with $\mathrm{P}_{0}^{\prime} / \mathrm{P}_{4}=3.5$ and at design speed with $\mathrm{P}_{0}^{\prime} / \mathrm{P}_{4}^{\prime}=4.0-$ traversing the span radially. 
Public reporting burden for this collection of information is estimated to average 1 hour per response, including the time for reviewing instructions, searching existing dala sources, gathering and maintaining the data needed, and completing and reviewing the collection of information. Send comments regarding this burden estimate or any other aspect of this collection of information, including suggestions 201-4302, and to the Otfice of Management and Budget, Papenwork Reduction Project (0704-0188), Washington, DC 20503.

\begin{tabular}{|l|c|c|}
\hline 1. AGENCY USE ONLY (Leave blank) & $\begin{array}{r}\text { 2. REPOAT DATE } \\
\text { June } 1993\end{array}$ & $\begin{array}{r}\text { A. REPOAT TYPE AND DATES COVERED } \\
\text { Technical Memorandum }\end{array}$ \\
\hline
\end{tabular}

4. TITLE AND SUBTTILE

Experimental Evaluation of a Cooled Radial-Inflow Turbine

6. AUTHOR(S)
5 FUMDIMG NUTIEERS

WU-535-05-10

Lizet Tirres, L. Danielle DiCicco, and Brent C. Nowlin

7. PERFORMING ORGANZATION MAME(S) AND ADDRESS(ES)

National Aeronautics and Space Administration

Lewis Research Center

Cleveland, Ohio 44135-3191

\section{SPONSORING/MONITORING AGENCY NAME(S) AND ADDRESS(ES)}

National Aeronautics and Space Administration

Washington, D.C. 20546-0001
8. PERFORHIMG ORGANDATON REPORT NUMBER

E-7948

\section{SUPPLEMENTAAY NOTES}

Prepared for the 29th AIAA Joint Propulsion Conference and Exhibit cosponsored by the AIAA, SAE, ASME, and ASEE, Monterey, California, June 28-30, 1993. Lizet Tirres, Sverdrup Technology, Inc., NASA Lewis Research Center Group, 2001 Aerospace Parkway, Brook Park, Ohio 44142 and L. Danielle DiCicco and Brent C. Nowlin, NASA Lewis Research Center. Responsible person, Lizet Tirres, (216) 826-6637.

12. DISTRIBUTION/AVALABRTY STATEMENT

12b. DISTRIBUTION CODE

Unclassified - Unlimited

Subject Category 07

\section{ABSTRACT (Max/mum 200 words)}

Two 14.4 inch tip diameter rotors were installed and tested in the Small Engines Component Turbine Facility (SECTF) at NASA Lewis Research Center. The rotors, a solid and a cooled version of a radial-inflow turbine, were tested with a 15 vane stator over a set of rotational speeds ranging from 80 to 120 percent design speed (17,500 to 21,500 rpm). The total-to-total stage pressure ratios ranged from 2.5 to 5.5 . The data obtained at the equivalent conditions using the solid version of the rotor are presented with the cooled rotor data. A Reynolds number of 381,000 was maintained for both rotors, whose stages had a design mass flow of $4.0 \mathrm{lbm} / \mathrm{sec}$, a design work level of $59.61 \mathrm{Btu} / \mathrm{bm}$, and a design efficiency of $87 \%$. The results include mass flow data, turbine torque, turbine exit flow angles, stage efficiency, and rotor inlet and exit surveys.

\section{SUBJECT TERMS}

\begin{tabular}{|l|l|}
\hline \multirow{2}{*}{} & $\begin{array}{c}\text { 15. NUMBER OF PAGES } \\
18\end{array}$ \\
\cline { 2 - 3 } & $\begin{array}{c}\text { 16. PRICE CODE } \\
\text { A03 }\end{array}$ \\
\hline $\begin{array}{l}\text { 19. SECURTY CLASSIFICATION } \\
\text { OF ABSTRACT } \\
\text { Unclassified }\end{array}$ & 20. LHATTATION OF ABSTRACT \\
\hline
\end{tabular}


